\title{
FRUIT FLIES (DIPTERA: TEPHRITIDAE) AND THEIR PARASITOIDS ASSOCIATED WITH DIFFERENT HOG PLUM GENOTYPES IN TERESINA, PIAUI'
}

\author{
LEONARDO DA SILVA SOUSA ${ }^{2}$, PAULO ROBERTO RAMALHO SILVA ${ }^{3}$, \\ MÁRCIA PATRÍCIA PAULA NASCIMENTO ${ }^{4}$, SOLANGE MARIA DE FRANÇA ${ }^{5}$, \\ ALMERINDA AMÉLIA RODRIGUES ARAÚJO ${ }^{6}$
}

\begin{abstract}
The aim of this work was to identify and quantify the infestation of fruit fly species and their parasitoids, associated with 20 hog plum genotypes (Spondias mombin L.) in a commercial orchard in Teresina, Piauí, Brazil. The survey was conducted by fruit sampling and monitoring through traps stocked with bait food, in the period from January to December 2012. Overall, 6560 fruits were collected (79.58 kg), resulting in 23059 pupae, of which 10080 fruit flies of the genus Anastrepha and 4984 braconid parasitoids emerged. Anastrepha obliqua species was the predominant with $99.92 \%$. F16P13 and F11P10 genotypes had the highest infestation indexes and F15P11 and F04P01 genotypes, the lowest. The main parasitoids collected were Opius bellus (77.65\%), Doryctobracon areolatus (19.88\%) and Utetes anastrephae (2.47\%). The average parasitism rate among genotypes was of $30.46 \%$. In traps, a total of 1434 fruit flies were collected, whose species were: A. obliqua (97.6\%), A. serpentina (1.4\%), A. fraterculus $(0.4 \%)$, A striata $(0.4 \%), A$. dissimilis $(0.1 \%)$, A. pseudoparallela $(0.1 \%)$. Anastrepha obliqua species was predominant in the area, based on faunistic analysis. The infestation index in the orchard was relevant for five months (January-May), coinciding with the period of availability of hog plum fruits, reaching the highest peak in March (2.86 FAT). There was a significant negative correlation between number of fruit flies in the orchard and the average air temperature, and a significant positive correlation with rainfall and relative humidity. However, the main factor that influenced the observed infestation index in the hog plum orchard was fruit availability.

Index terms: Anastrepha obliqua, PET traps, Opius bellus, Spondias mombin.
\end{abstract}

\section{MOSCAS-DAS-FRUTAS (DIPTERA: TEPHRITIDAE) E SEUS PARASITOIDES EM DIFERENTES GENÓTIPOS DE CAJÁ EM UM POMAR COMERCIAL DE TERESINA, PIAUÍ}

\begin{abstract}
RESUMO - Objetivou-se com este trabalho identificar e quantificar a infestação de espécies de moscasdas-frutas e seus parasitoides, associadas a 20 genótipos de cajazeira (Spondias mombin L.) em um pomar comercial no município de Teresina-PI. Frutos caídos foram coletados, e armadilhas com atrativo alimentar foram instaladas no pomar, no período de janeiro a dezembro de 2012. Foram coletados 6.560 frutos (79, $58 \mathrm{~kg}$ ), obtendo-se 23.059 pupários, dos quais emergiram 10.080 moscas-das-frutas do gênero Anastrepha e 4.984 parasitoides braconídeos. A espécie A. obliqua foi a predominante, com 99, $92 \%$. Os genótipos F16P13 e F11P10 apresentaram maiores índices de infestação, e os genótipos F15P11 e F04P01, os menores. Os principais parasitoides coletados foram Opius bellus $(77,65 \%)$, Doryctobracon areolatus $(19,88 \%)$ e Utetes anastrephae (2, $47 \%)$. O índice de parasitismo médio entre os genótipos foi de 30, 46\%. Nas armadilhas, foi coletado um total de 1.434 moscas-das-frutas, cujas espécies encontradas foram: A. obliqua, (97, $6 \%)$, A. serpentina $(1,4 \%)$, A. fraterculus $(0,4 \%)$, A. striata $(0,4 \%)$, A. dissimilis $(0,1 \%)$, A. pseudoparallela $(0,1 \%)$. A espécie $A$. obliqua foi a predominante na área, com base na análise faunística calculada. O índice de infestação no pomar foi relevante durante cinco meses (janeiro a maio), período de disponibilidade de frutos de cajazeira. Houve uma correlação significativa negativa entre o número de moscas-das-frutas no pomar e a temperatura média do ar, e correlação significativa positiva com a precipitação pluviométrica e umidade relativa do ar. Entretanto, o principal fator constatado que influenciou o índice de infestação no pomar de cajazeira foi à disponibilidade de frutos.

Termos para indexação: Spondias mombin, Anastrepha obliqua, Opius bellus, Armadilhas tipo "PET".

'(Paper 021-16). Received Jnuary 26, 2016. Accepted August 18, 2016.Part of the master's thesis of the first author presented to the Graduate Program in Agronomy, PPGA of the Federal University of Piauí.

${ }^{2}$ Agronomist. UFPI. Email: z-leoonline@hotmail.com

${ }^{3}$ Agronomist. PhD., Professor at UFPI: Phytosanitary, Deptof Plant Technology - CCA. Teresina-PI. Email: pramalhoufpi@yahoo.com.br ${ }^{4}$ Agronomist., Federal University of Piauí, Email: marciappn@hotmail.com

${ }^{5}$ Agronomist., Post-doctorate of the Graduate Program in Agronomy-Tropical Agriculture / UFPI. Email: solangeufrpe@yahoo.com.br ${ }^{6}$ Biologist. MsC, Professor at SEDUC. Teresina, PI. PhD student at the UEMA Graduate Program in Agroecology. São Luís, MA. Email: a.araraujo@bol.com.br
\end{abstract}




\section{INTRODUCTION}

The genus Spondias L. (Anacardiaceae) stands out among tropical fruit trees with the highest potential for exploration and agroindustrial use, and Spondias mombin L. is a hog plum genotype very appreciated with growing commercialization in the northern and northeastern regions of Brazil (SILVA JUNIOR et al., 2004). However, S. mombin is still a species in domestication, and the available knowledge and technologies are still insufficient for its cultivation on a commercial scale. Therefore, its main form of exploitation is still extractive (SACRAMENTO; SOUZA, 2009).

Among the phytosanitary aspects, infestation by fruit flies (Diptera: Tephritidae) is considered the major bottleneck in its production, commercialization and export, characterizing as the most important fruit pest in the country, causing direct and indirect damages, with high adaptability to other regions when introduced (quarantine pest) (GODOY et al., 2007). Their losses are due to both oviposition and feeding of larvae that accelerate maturation and cause the early fall of fruits, impairing marketing and use in industry, in addition to phytosanitary barriers imposed by importing countries (SANTOS et al., 2012). Fruit flies of the genus Anastrepha Schiner and Ceratitis capitata (Wied.) are one of the main phytosanitary problems of the Brazilian fruit-growing sector (GARCIA; NORRBOM, 2011).

Due to the socioeconomic importance of hog plum in the northern and northeastern regions of Brazil and its potential expansion in commercial orchards through the selection of superior genotypes, phytosanitary surveys are required. In this regard, special consideration should be given to the occurrence of fruit flies and their parasitoids in order to obtain subsidies for the adoption of rational control measures in commercial areas.

The aim of this study was to perform a survey on the occurrence and infestation of fruit fly species and their natural parasitoids in different $S$. mombin genotypes in a commercial orchard in the municipality of Teresina-PI, as well as population fluctuation, faunistic analysis and correlation with climatic factors of these tephritids in the area.

\section{MATERIAL AND METHODS}

The study was carried out in the municipality of Teresina-Piaui, in the Serra do Gaviao community, in a commercial orchard with area of 13.73 ha, composed of 542 caja plants spaced $15 \times 15$ meters.
The orchard is located at $04^{\circ} 58^{\prime} 31.93$ "S and $42^{\circ}$ $41^{\prime} 02.37$ ' $\mathrm{W}$ and altitude of $178 \mathrm{~m}$ a.s.l. being surrounded by native forest and small farms. The region presents tropical climate with summer and autumn rains, with average annual precipitation of $1,377 \mathrm{~mm}$, being higher in the months of March and April. It presents average annual potential evapotranspiration of $2,973 \mathrm{~mm}$, annual air relative humidity of $69.9 \%$ and average annual temperature of $28^{\circ} \mathrm{C}$ (MEDEIROS, 2006).

Fruit collection and monitoring of fruit flies and their parasitoids: The genotypes selected for evaluation were: F01P07, F04P01, F04P08, F09P08, F09P10, F11P06, F11P10, F14P07, F14P08, F14P09, F15P11, F16P02, F16P13, F16P14, F17P09, F18P01, F18P02, F19P01 and F20P12. Fruits newly felt on the ground were collected, 40 fruits per plant of each genotype, according to the fruiting period of each genotype. Collections were carried out weekly from January to May 2012. The criteria for choosing these genotypes were their technological characteristics, based on their soluble solids content ( ${ }^{\circ}$ Brix), according to Santana (2010). Fruits were transported to the laboratory, weighed and distributed in plastic trays, lined with $5 \mathrm{~cm}$ of sand (sieved, autoclaved and moist) to serve as a substrate for pupation and covered with voile fabric, bound in the edges using rubber band. After 10 to 12 days, rotten fruits were removed and the sand was sifted to separate pupar, which were stored in glass flasks containing $2 \mathrm{~cm}$ of wet sand. After the emergence of adults, they remained for two days in the containers in order to fix the wing bands. Subsequently, screening was carried out, and flies were separated from parasitoids, and both conserved in $70 \%$ alcohol in sealed test tubes for later specific identification.

Monitoring of traps: The monitoring of fruit fly species collected in traps was carried out weekly in a period of one year (January to December 2012), totaling 53 collections. Six PET-type traps were installed inside the orchard, divided in two rows with three traps following the methodology of Aguiar-Menezes et al. (2006), the distance between traps in the same row was stipulated at 90 meters and, between rows, at 110 meters. The attractive food used was $7 \%$ sugarcane molasses $(35 \mathrm{~mL}$ of molasses diluted in $465 \mathrm{~mL}$ of water for the preparation of $500 \mathrm{~mL}$ of solution), renewed weekly at the time of each collection. Each trap received 300 $\mathrm{mL}$ of the attractant and was installed at a height of $3 / 4$ of the plant from the soil surface (AGUIARMENEZES et al., 2006). The specimens captured 
in traps were packed in plastic containers and taken to the laboratory, where they were sorted and kept in $70 \%$ alcohol in test tubes for subsequent specific identification.

Identification of species: The identification of fruit flies of the genus Anastrepha was based on females according to taxonomic keys elaborated by Zucchi (2000a) and Montes et al. (2013), since males were identified only at the gender level for not presenting specific taxonomic features. Parasitoids were identified according to the taxonomic keys of Canal and Zucchi (2000) and Marinho et al. (2011). The identified parasitoid species were confirmed by expert Dr. Ranyse Barbosa Querino, researcher at Embrapa Meio-Norte. The identified material was included in the entomological collection of the Laboratory of Plant Heath (Department of Plant Technology / CCA, UFPI) for possible consultations.

Based on data obtained from the total fruit collections by genotype, the infestation indexes of genotypes, the frequency of fruit fly and parasitoid species, the pupal viability and the parasitism rate were defined. The species frequency was calculated considering the number of each species found by the total number of species. The fruit infestation index was calculated according to Araujo et al. (2005), the pupal viability (SOUZA-FILHO, 2006), and the parasitism rate (PARANHOS et al., 2007).

Statistical analysis among genotypes: Data on infestation indexes (puparia / fruit and puparia / $\mathrm{kg}$ ) pupal viability of fruit flies and the parasitism rate associated with each genotype obtained were submitted to statistical analysis to verify if there were significant differences among genotypes evaluated for fruit fly infestation and parasitism. For this, the Kruskal-Wallis nonparametric test was performed at 5\% probability (SIEGEL; CASTELLAN JÚNIOR, 2006). The BioEstat 5.0 statistical software (AYRES et al., 2007) was used to perform calculations.

Faunistic analysis of fruit fly species captured in traps: The data obtained were analyzed with ANAFAU software (MORAES et al., 2003). This software calculates the faunal indexes: Abundance, Dominance, Frequency, and Constancy (SILVEIRA NETO et al., 1976; URAMOTO et al., 2005), in addition to the Shannon-Weaner diversity indexes $\left(\mathrm{H}^{\prime}\right)$, richness (Margalef) and equitability (modified Hill index), according to Uramoto et al. (2005). Predominant species were those that obtained higher values in all calculated faunal indexes
(SILVEIRA NETO et al., 1995).

Calculation of the infestation level of fruit flies by means of traps: The FTD index (fly / trap / day) was used to estimate the level of monthly infestation level of tephritids in the orchard (CARVALHO, 2005).

Correlation of the fluctuation of fruit flies captured in traps with climatic factors: To correlate the weekly number of adult fruit flies to the weekly averages of relative humidity (\%), average air temperature $\left({ }^{\circ} \mathrm{C}\right)$ and weekly rainfall accumulations $(\mathrm{mm})$ for the collection period, the Spearman nonparametric correlation coefficient $(\rho)$ was used, at $5 \%$ significance level of the BioEstat 5.3 software (AYRES et al., 2007). The weekly climatic data of pluviometric precipitation, relative air humidity and air temperature in the municipality of Teresina - PI were obtained through the database of the National Institute of Meteorology (INMET) website (INMET, 2013).

\section{RESULTS AND DISCUSSION}

A total of 6560 fruits with weight equivalent to $79.58 \mathrm{~kg}$ were harvested, of which 23059 puparia were obtained. About 15064 insects emerged, of which $66.91 \%$ were fruit flies and $33.09 \%$ were parasitoids. Among fruit flies, $49.10 \%$ were females, and $50.90 \%$ males, all belonging to the genus Anastrepha.

The pupal viability was higher in F20P12, F17P09, F16P14, F14P09, F11P10, F11P06, F07P08 and F01P07 genotypes. The lowest value was observed in F18P01 genotype, below 50\% (Table 1). High pupal viability indicates that the fruit conditions and also the environmental factors contributed to the success of the species (CARVALHO, 2005), thus demonstrating the great adaptation of the species to the host. The mean pupal viability among hog plum genotypes was $65.31 \%$.

F16P13 and F11P10 genotypes presented the highest infestation indexes of tephritids, statistically differing from F04P01 and F15P11 genotypes, which stood out as the less attacked genotypes; in fruits of the other genotypes, infestation indexes were intermediate. The mean infestation indexes of genotypes were 3.79 puparia / fruit and 317.46 puparia / $\mathrm{kg}$ (Table 1). These results demonstrate that the fruit fly infestation index varied according to the genotype. In general, differences in intrinsic and / or extrinsic characteristics, such as physicochemical and fruit availability period, as well 
as environmental factors may have contributed to such variations (MALAVASI, MORGANTE, 1980; SUPLICY FILHO et al., 1984).

Anastrepha obliqua (Macquart) was the dominant species in hog plum genotypes studied, with a total of 4945 individuals and a relative frequency of $99.92 \%$. Four Anastrepha spp. specimens (0.08\%) were also found. The high infestation of $A$. obliqua in hog plum fruits in the state of Piauí may be related to the concentration of the same host in localities where fruits were collected. According to Malavasi; Morgante (1980), the natural infestation of tephritids is influenced, among other factors, by the population density of primary hosts, presence of alternative hosts and degree of susceptibility of fruits to oviposition and larval development.

The preference of $A$. obliqua by genus Spondias, especially $S$. mombin, has been observed not only in the state of Piaui (ARAÚJO et al., 2014) but also in several other states, such as Rio de Janeiro (LEAL et al. 2009), Minas Gerais (PIROVANI et al., 2010), Bahia (BITTENCOURT et al., 2012), and Amapa (DE DEUS, ADAIME, 2013).

From puparia collected, 4984 parasitoids emerged, Doryctobracon areolatus (Szépligeti), Opius bellus Graham and Utetes anastrephae (Viereck) (Braconidae). The parasitism rates of hog plum genotypes ranged from $11.04 \%$ to $54.69 \%$. The genotypes that presented the highest parasitism rates were: F11P6, F01P07, F14P09 and F16P14. F18P02 genotype showed the lowest parasitism rate, and the overall mean parasitism rate was $30.46 \%$ (Table 2 ).

F01P07 and F11P06 genotypes had parasitism above 50\% (Figure 1). According to Canal; Zucchi (2000), the natural parasitism rates in fruit flies found in most works rarely exceed $50 \%$. The high parasitism rate found may be related to the high infestation index of flies in hog plum fruits. According to Araujo; Zucchi (2002), these factors are positively correlated. Fruits of species belonging to Spondias, in general, favor a higher natural parasitism rate of tephritids in relation to other fruits with thicker pulps, since fruits are small and have relatively thin pulp thickness. This facilitates reaching the larvae of fruit flies by the ovipositor of parasitoids.

Among the parasitoids found, O. bellus showed the highest frequency in the parasitism of A. obliqua in all hog plum genotypes, obtaining general average frequency of $77.65 \%$, followed by $D$. areolatus, with $19.88 \%$ and finally $U$. anastrephae, with frequency of $2.47 \%$. Similar results were observed by Araújo et al. (2014), who also recorded parasitism frequency in $A$. obliqua by $O$. bellus (78.61\%) followed by $D$. areolatus $(21.39 \%)$ in the municipality of Teresina. In other areas, the frequency of $D$. areolatus is higher than that of O. bellus (ALVARENGA et al., 2009; ARAUJO, ZUCCHI, 2002; MONTES et al., 2011) and that of $U$. anastrephae (BITTENCOURT et al. 2012). The justification for this may be the that the ovipositor of $O$. bellus and $U$. anastrephae is shorter in relation to that of $D$. areolatus, therefore they are more agile in the parasitism of tephritids in small fruits, such as those of $S$. mombin, but the behavior of these species is influenced by local characteristics, and may vary at different times of the year (CANAL, ZUCCHI, 2000).

Overall, 1433 fruit flies of the genus Anastrepha (598 males and 835 females) were captured in traps. Seven species were identified: A. obliqua $(97.6 \%)$, A. serpentina (Wiedemann) (1.4\%), A. fraterculus (Wiedemann) (0.4\%), A. striata Shiner $(0.4 \%), A$. dissimilis Stone $(0.1 \%)$ and $A$. pseudoparallela (Loew) $(0.1 \%)$. Thus, $A$. obliqua was the predominant species with the following faunistic characteristics: superdominant (SD), superabundant (SA), superfrequent (sf), and constant (W) (Table 3).

The predominance of $A$. obliqua indicates its preference for this host. Although A. obliqua is considered a polyphagous species, it has a close relationship of preference for Anacardiaceae fruits, such as Spondias mombin (URAMOTO et al., 2004; ARAUJO et al., 2005), which justifies the greater capture and frequency of this species in traps. Although A. serpentina has been captured in traps, there is a significant difference compared to the frequency of A. obliqua. Although $A$. serpentina is considered polyphagous (ZUCCHI, 2008), it has preference for Sapotaceae fruits (SELIVON, 2000). As $A$. fraterculus prefers Anacardiaceae hosts (ZUCCHI, 2000b), A. striata prefers Myrtaceae fruits such as guava (Psidium guajava) (MALAVASI et al., 2000; KOVALESKI et al., 2000) and A. pseudoparallela and $A$. dissimilis species prefer Passifloraceae fruits, such as passion fruit (SELIVON, 2000), which justifies the reduced number of these species in traps. The presence of other less frequent fruit fly species in the orchard can be attributed to the existence of nearby agroecosystems with other preferential host plants and / or native vegetation, which probably may have contributed to the occurrence of accessory and / or accidental species in the samples collected (AZEVEDO et al., 2010).

The hog plum orchard presented low diversity of fruit fly species, highlighted by the low Shannon diversity index, prevailing only one species, as well as low richness index (Margalef). The 
Equitability index (modified Hill index) revealed lower uniformity in the distribution of tephritid species in the orchard (Table 4). These indexes prove the predominance of a species. The richness index value in the orchard was almost inexpressive, since according to Margalef (1972), this index rarely exceeds the value of 4.5 , usually ranging from 1.5 to 3.5. Silveira Neto et al. (1976) explain that the diversity index values tend to be low in places where limiting factors and interspecific competition act intensely. In these places, the most common species increase their populations and rare species present low population level.

In the population fluctuation of fruit flies, it was observed that the majority of fruit flies $(99.65 \%)$ were captured in the period from January to May 2012, and from June to December, the percentage was $0.35 \%$ (Figure 2). The high population density of $A$. obliqua coincides with the fruiting period of hog plum fruits, which is from January to May, indicating that hosts must be available for tephritids to complete their life cycles and to maintain their adult populations in certain areas. According to Souza-Filho et al. (2009), the spatial distribution of fruit flies is mainly related to the availability and distribution of their host plants.

The infestation index of fruit flies was relevant during five months (January to May), peaking in March (2.86 FTD). In the months from June to December, tephritids were hardly captured, coinciding with the end of the fruiting period and subsequent leaf senescence of $S$. mombin fruits, as well as the beginning of their vegetative renewal (Figure 2). The FTD index was higher than 0.40 between January and May 2012. According to Carvalho (2005), this characterizes area of high prevalence of fruit fly infestation, requiring the adoption of measures of control or suppression of the pest and when the FTD index is equal to or greater than 0.5 fly / trap / day, chemical control should be immediately adopted.

Based on the Spearman correlation analysis ( $\rho$ ) between population fluctuation of flies and climatic variables, it was verified that all of them significantly influenced $(p<0.05)$ the number of these insects present in the area. The mean air temperature ( $\rho=-0.5665 ; p=0.0001)$ was negatively correlated, that is, as the temperature increased, the number of flies decreased. Rainfall $(\rho=0.6346, p=0.0001)$ and relative air humidity $(\rho=0.8306 ; p=0.0001)$ presented positive correlations with the population of flies, that is, when the values of these variables increased or decreased the amount of tephritids suffered a variation in the same direction (Table 5).
However, although the correlation results showed a significant influence of climatic factors on population fluctuation of fruit flies in the orchard (Table 5), fruit availability was preponderant, since the number of tephritids captured in traps was high when fruiting occurred. However, when this availability ceased, fruit flies practically disappeared from the area and were not captured by traps (Figure 2 ). Thus, there are other factors, in addition to climatic variables, that can influence the population fluctuation of fruit flies in an orchard. Montes et al. (2011) argue that the availability of host fruits and the maturation stage of fruits are factors more determinant in the population levels of fruit flies than climatic factors. According to Souza-Filho et al., (2000), the behavior of flies varies greatly in relation to meteorological parameters, especially the location and the year, as well as the host species and the maturation period of fruits. 
TABLE 1- Collection period, infestation indexes and pupal viability of tephritids obtained in 20 hog plum fruit genotypes (Spondias mombin L.), collected at the commercial orchard at the "Serra do Gavião", Teresina, Piauí, Brazil (045' 31.93 "S and $42^{\circ} 41.02 .37^{\circ}$ 'W, altitude 178 m a.s.l.).

\begin{tabular}{|c|c|c|c|c|c|c|c|c|c|c|c|c|}
\hline \multirow{3}{*}{$\begin{array}{l}\text { Genotypes } \\
\text { F01P07 }\end{array}$} & \multirow{3}{*}{$\begin{array}{c}\text { Collection period }^{(1)} \\
\text { February to March/12 }\end{array}$} & \multicolumn{8}{|c|}{ Infestation indexes ${ }^{(2)}$} & \multirow{2}{*}{\multicolumn{3}{|c|}{ Pupal viability $(\%)^{(2}$}} \\
\hline & & \multicolumn{4}{|c|}{ Puparia/ fruits } & \multicolumn{4}{|c|}{ Puparia/ Kg } & & & \\
\hline & & 1.34 & & d & & 149.54 & & c & d & 75.93 & $\mathbf{a}$ & \\
\hline F03P11 & March to May/12 & $3.68 \mathbf{a}$ & $\mathbf{b}$ & c d & & 308.42 & $\mathbf{a} \quad \mathbf{b}$ & c & & 65.60 & $\mathbf{a}$ & B \\
\hline F04P01 & April to May/12 & 0.93 & & & e & 91.90 & & & d & 56.31 & $\mathbf{a}$ & B \\
\hline F04P11 & March to May /12 & $3.74 \mathbf{a}$ & $\mathbf{b}$ & c & & 268.98 & $\mathbf{a} \mathbf{b}$ & c & d & 59.66 & $\mathbf{a}$ & B \\
\hline F07P08 & March to May /12 & $4.82 \mathbf{a}$ & $\mathbf{b}$ & c & & 410.19 & a $\mathbf{b}$ & & & 66.20 & $\mathbf{a}$ & \\
\hline F09P10 & April to May /12 & 2.19 & $\mathbf{b}$ & c d & $\mathbf{e}$ & 220.44 & b & c & d & 57.84 & $\mathbf{a}$ & B \\
\hline F11P06 & January to April /12 & $3.38 \mathbf{a}$ & $\mathbf{b}$ & c d & e & 318.24 & a $\mathbf{b}$ & c & & 76.41 & $\mathbf{a}$ & \\
\hline F11P10 & March to April/12 & $7.65 \mathrm{a}$ & & & & 518.86 & $\mathbf{a}$ & & & 71.77 & $\mathbf{a}$ & \\
\hline F14P07 & March to May /12 & $3.40 \mathbf{a}$ & $\mathbf{b}$ & c d & e & 233.91 & b & c & d & 62.47 & $\mathbf{a}$ & B \\
\hline F14P08 & April to May /12 & $3.65 \mathrm{a}$ & $\mathbf{b}$ & c d & e & 407.37 & $\mathbf{a} \quad \mathbf{b}$ & & & 59.52 & $\mathbf{a}$ & B \\
\hline F14P09 & January to April /12 & 3.18 & $\mathbf{b}$ & c d & e & 321.47 & a $\mathbf{b}$ & c & & 68.45 & $\mathbf{a}$ & \\
\hline F15P11 & March to May /12 & 1.56 & & c d & e & 89.66 & & & d & 59.04 & $\mathbf{a}$ & B \\
\hline F16P02 & April to May /12 & $4.01 \mathbf{a}$ & $\mathbf{b}$ & c & & 298.31 & a $\mathbf{b}$ & c & d & 56.18 & $\mathbf{a}$ & B \\
\hline F16P13 & April to May 12 & $11.51 \mathbf{a}$ & & & & 1131.48 & $\mathbf{a}$ & & & 55.32 & $\mathbf{a}$ & B \\
\hline F16P14 & January to April /12 & 2.73 & $\mathbf{b}$ & c d & e & 319.79 & $\mathbf{a} \quad \mathbf{b}$ & c & & 73.29 & $\mathbf{a}$ & \\
\hline F17P09 & March to April /12 & $4.87 \mathbf{a}$ & $\mathbf{b}$ & & & 375.62 & a $\quad b$ & c & & 67.92 & $\mathbf{a}$ & \\
\hline Mean & 164 & & 3.7 & & & & 317.46 & & & & & \\
\hline
\end{tabular}

(1) The collection period varied according to the fruiting time and the availability of mature fruits of genotypes evaluated. ${ }^{(2)}$ Means followed by the same letter in the same column do not differ by the Kruskal-Wallis nonparametric test at $5 \%$ probability. 
TABLE 2- Total of individuals, parasitism rates and relative frequency of fruit fly parasitoid species found in hog plum fruit genotypes (Spondias mombin L.) of a commercial orchard at Serra do Gavião, municipality of Teresina, Piauí, Brazil (0458’31.93 “S, $42^{\circ} 41^{\circ} 02.37^{\prime}$ ” W, altitude $178 \mathrm{~m}$ a.s.1.).

\begin{tabular}{|c|c|c|c|c|c|c|c|c|}
\hline \multirow{3}{*}{$\begin{array}{c}\text { Genotypes } \\
\text { F01P07 }\end{array}$} & \multicolumn{3}{|c|}{ Braconid Species } & \multirow{3}{*}{$\begin{array}{c}\text { Total } \\
175\end{array}$} & \multirow{2}{*}{\multicolumn{4}{|c|}{ Parasitism rates $(\%)$}} \\
\hline & \multirow{2}{*}{$\begin{array}{c}\begin{array}{c}\text { Doryctobracon } \\
\text { areolatus }\end{array} \\
42\end{array}$} & \multirow{2}{*}{$\begin{array}{c}\text { Opius bellus } \\
132 \\
\end{array}$} & \multirow{2}{*}{$\begin{array}{c}\text { Utetes anastrephae } \\
1\end{array}$} & & & & & \\
\hline & & & & & 50.35 & $\mathbf{a}$ & & \\
\hline F03P11 & 25 & 79 & 14 & 118 & 17.26 & & $\mathbf{b}$ & $\mathbf{C}$ \\
\hline F04P01 & 0 & 24 & 2 & 26 & 22.03 & $\mathbf{a}$ & $\mathbf{b}$ & \\
\hline F04P11 & 23 & 78 & 1 & 102 & 16.76 & & $\mathbf{b}$ & c \\
\hline F07P08 & 57 & 107 & 2 & 166 & 18.49 & & $\mathbf{b}$ & c \\
\hline F09P10 & 10 & 41 & 4 & 55 & 16.16 & & $\mathbf{b}$ & c \\
\hline F11P06 & 174 & 437 & 4 & 615 & 54.69 & $\mathbf{a}$ & & \\
\hline F11P10 & 130 & 541 & 21 & 692 & 42.07 & $\mathbf{a}$ & $\mathbf{b}$ & c \\
\hline F14P07 & 27 & 228 & 10 & 265 & 30.02 & $\mathbf{a}$ & $\mathbf{b}$ & c \\
\hline F14P08 & 30 & 164 & 10 & 204 & 32.07 & $\mathbf{a}$ & $\mathbf{b}$ & c \\
\hline F14P09 & 124 & 435 & 17 & 576 & 49.31 & $\mathbf{a}$ & & \\
\hline F15P11 & 15 & 44 & 0 & 59 & 30.35 & $\mathbf{a}$ & $\mathbf{b}$ & c \\
\hline F16P02 & 4 & 76 & 3 & 83 & 22.33 & $\mathbf{a}$ & $\mathbf{b}$ & c \\
\hline F16P13 & 8 & 156 & 12 & 176 & 14.66 & & $\mathbf{b}$ & c \\
\hline F16P14 & 90 & 432 & 13 & 535 & 48.97 & $\mathbf{a}$ & & \\
\hline F17P09 & 39 & 213 & 0 & 252 & 32.81 & $\mathbf{a}$ & $\mathbf{b}$ & c \\
\hline F18P01 & 2 & 12 & 0 & 14 & 17.01 & & $\mathbf{b}$ & c \\
\hline F18P02 & 28 & 63 & 0 & 91 & 11.04 & & & c \\
\hline F19P01 & 30 & 264 & 7 & 301 & 39.34 & $\mathbf{a}$ & $\mathbf{b}$ & \\
\hline F20P12 & 133 & 344 & 2 & 479 & 43.42 & $\mathbf{a}$ & $\mathbf{b}$ & \\
\hline Total & 991 & 3870 & 123 & 4984 & & & & \\
\hline Freq. (\%) & 19.88 & 77.65 & 2.47 & Mean & 30.46 & & & \\
\hline
\end{tabular}

* Index values followed by the same letter do not differ by the nonparametric Kruskal-Wallis test at 5\% probability. 


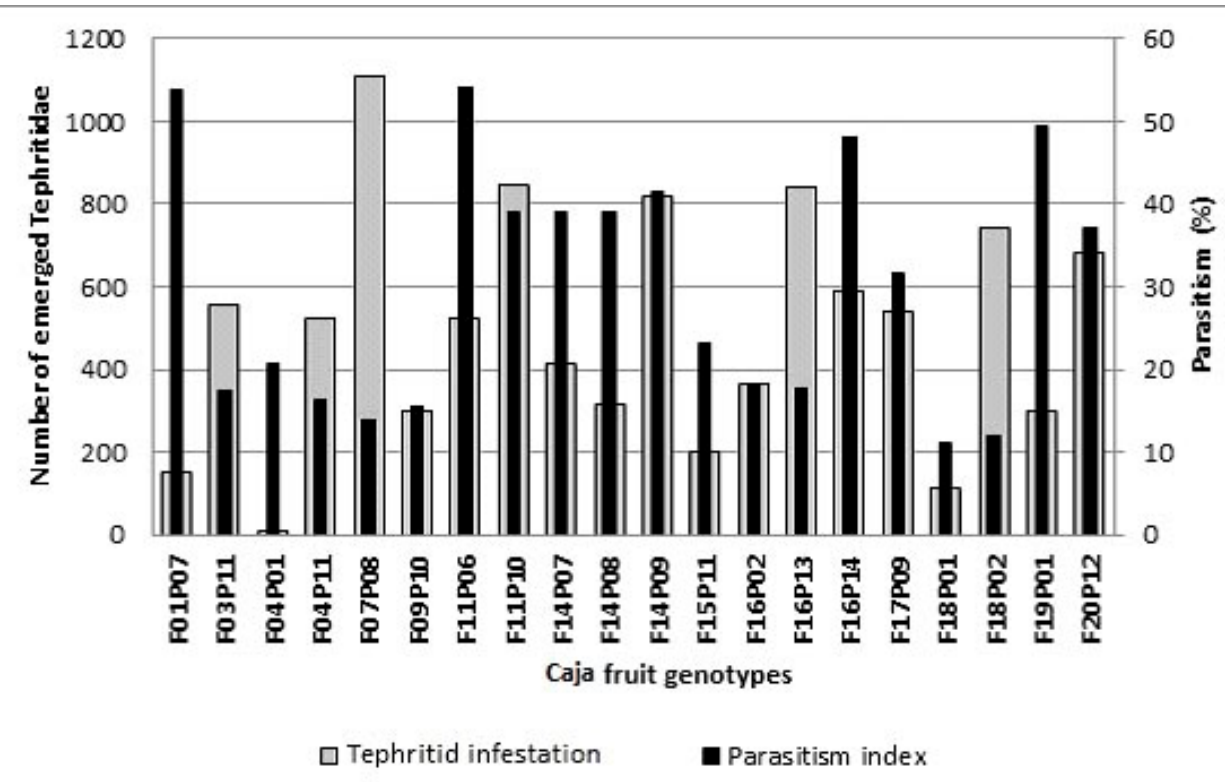

FIGURE 1- Relationship between parasitism rates and infestations of tephritids in caja notypes (Spondias mombin L.) of a commercial orchard at Serra do Gaviao, Teresina, Piaui, Brazil (04 $58^{\prime} 31.93$ " $\mathrm{S}$ and $42^{\circ} 41^{\prime} 02.37$ "W. altitude $178 \mathrm{~m}$ a.s.1.).

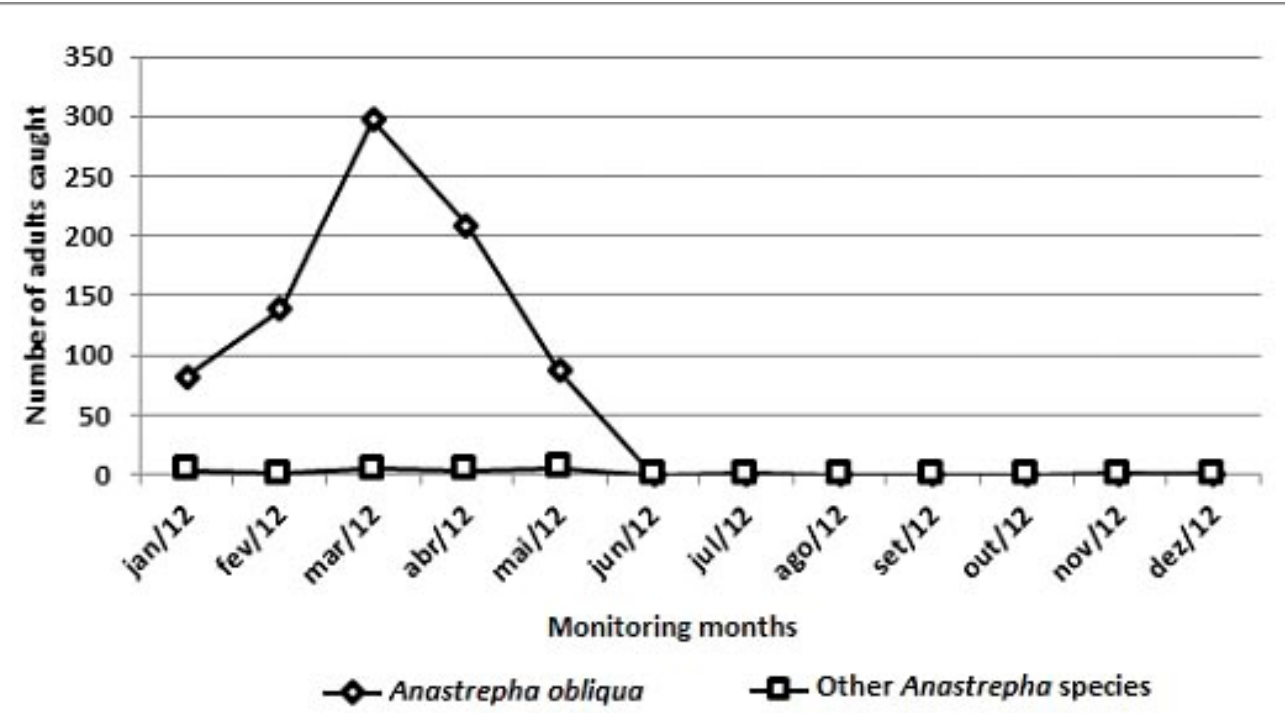

FIGURE 2- Population fluctuation of Anastrepha species captured in PET traps installed in a commercial hog plum orchard (Spondias mombin L.) located at Serra do Gavião, Teresina, Piaui, Brazil $\left(04^{\circ} 58^{\prime} 31.93\right.$ “ $\mathrm{S}$ and $42^{\circ} 41^{\prime} 02.37^{\prime \prime W}$. altitude $178 \mathrm{~m}$ a.s.l.) from January to December 2012. 
TABLE 3 - Faunal analysis of fruit fly species captured in PET traps installed in a commercial hog plum orchard (Spondias mombin L.) located at Serra do Gaviao, Teresina, Piaui, Brazil (04\%58’31.93 “ S and $42^{\circ} 41^{\prime} 02.37$ 'W. altitude $178 \mathrm{~m}$ a.s.1.) from January to December 2012.

\begin{tabular}{|c|c|c|c|c|c|c|}
\hline Anastrepha species & $\mathbf{N}$ & NC & D & $\mathbf{A}$ & $\mathbf{F}$ & $\mathrm{C}$ \\
\hline Anastrepha obliqua (Macquart) & 816 & 24 & $\mathrm{sd}$ & $\mathrm{sa}$ & SF & $\mathrm{W}$ \\
\hline Anastrepha serpentina (Wiedemann) & 11 & 9 & $\mathrm{~d}$ & $\mathrm{ma}$ & MF & $\mathrm{Y}$ \\
\hline Anastrepha fraterculus (Wiedemann) & 3 & 2 & nd & $\mathrm{c}$ & $\mathrm{F}$ & $\mathrm{Y}$ \\
\hline Anastrepha striata Shiner & 3 & 2 & nd & $\mathrm{c}$ & $\mathrm{F}$ & $\mathrm{Y}$ \\
\hline Anastrepha dissimilis Stone & 1 & 1 & nd & $\mathrm{c}$ & $\mathrm{F}$ & $\mathrm{Y}$ \\
\hline Anastrepha pseudoparallela (Loew) & 1 & 1 & nd & $\mathrm{c}$ & $\mathrm{F}$ & $\mathrm{Y}$ \\
\hline Total & 835 & & & & & \\
\hline
\end{tabular}

TABLE 4- Diversity index of Anastrepha species captured in PET traps installed in a commercial hog plum orchard (Spondias mombin L.) located at Serra do Gaviao, Teresina, Piaui, Brazil (045' 31.93 “'S and $42^{\circ} 41^{\prime} 02.37^{\prime \prime W}$. altitude $178 \mathrm{~m}$ a.s.l.) from January to December 2012.

\begin{tabular}{lc}
\hline \multicolumn{1}{c}{ INDEXES } & VALUES \\
\hline Total number of individuals & 836 \\
Number of species & 07 \\
Total collections $\quad$ Diversity & 52 \\
& \\
Diversity index (Shannon-Weaner) & $\mathrm{H}=0,1452$ \\
H confidence interval & {$[0.143292 ; 0.147048]$} \\
Richness index (Margalef) & 0.8917 \\
$\quad$ Equitability & \\
Modified Hill index (E) & 0.0746 \\
\hline
\end{tabular}

TABLE 5 - Spearman nonlinear correlation $(\rho)$ between weekly number of fruit flies caught in traps from January to December 2012 in a commercial hog plum orchard (Spondias mombin L.) located at Serra do Gaviao, Teresina, Piaui, Brazil (04'58'31.93 "S and $42^{\circ} 41^{\prime} 02.37^{\prime}$ " W. altitude of $178 \mathrm{~m}$ a.s.1.) and weekly values of climatic factors in the municipality referring to the period.

\begin{tabular}{clcc}
\hline Variable trap capture & \multicolumn{1}{c}{ Variable climatic factors } & value $(\mathbf{p})^{*}$ & Correlation $(\boldsymbol{\rho})$ \\
\hline \multirow{2}{*}{$\begin{array}{c}\text { Number of fruit flies } \\
\text { captured }\end{array}$} & Average air temperature & $0.0001^{*}$ & -0.5665 \\
& Rainfall & $0.0001^{*}$ & 0.6346 \\
& Air relative humidity & $0.0001^{*}$ & 0.8306 \\
\hline
\end{tabular}

* Significant correlation: $\mathrm{p}<0.05$. 


\section{CONCLUSIONS}

Anastrepha obliqua species was the dominant in the infestations of Spondias mombin fruit genotypes in a commercial orchard in the municipality of Teresina-PI.

Doryctobracon areolatus, Opius bellus and Utetes anastrephae species were identified parasitizing A. obliqua in Spondias mombin fruit genotypes in the municipality of Teresina-PI, $O$. bellus being more frequent in relation to the others.

The high average air temperature causes a decrease in the population fluctuation of fruit flies in the orchard, while the increase of the relative air humidity and the increase in rainfall volume increases the population fluctuation; however, the main factor of variation in the population fluctuation of tephritids was fruit availability.

\section{REFERENCES}

AGUIAR-MENEZES, E.; SOUZA, J. F.; SOUZA, S. A. S.; LEAL, M. R.; COSTA, J. R.; MENEZES, E. B. Armadilha PET para captura de adultos de moscas-das-frutas em pomares comerciais e domésticos. Seropédica: Embrapa Agrobiologia, 2006. (Circular Técnica, 16).

ALVARENGA, C. D.; MATRANGOLO, C. A. R.; LOPES, G. N.; SILVA, M. A.; LOPES, E. N.; ALVES, D. A.; NASCIMENTO, A. S.; ZUCCHI, R. A. Moscas-das-frutas (Diptera: Tephritidae) e seus parasitóides em plantas hospedeiras de três municípios do norte do estado de Minas Gerais. Arquivos do Instituto Biológico, Campinas, v.76, n.2, p.195-204, 2009.

ARAÚJO, A.A.R.; SILVA, P.R.R.; QUERINO, R.B.; SOUZA, E.P.S.; SOARES, L.L. Moscas-dasfrutas (Diptera: Tephritidae) associadas às frutíferas nativas de Spondias spp.(Anacardiaceae) e Ximenia americana L. (Olacaceae) e seus parasitoides no estado do Piauí, Brasil. Semina: Ciências Agrárias, Londrina, v.35, n.4, p.1739-1750, 2014.

ARAUJO, E.L.; MEDEIROS, M.K.M.; SILVA, V.E.; ZUCCHI, R.A. Moscas-das-frutas (Diptera: Tephritidae) no semi-árido do Rio Grande do Norte: plantas hospedeiras e índices de infestação. Neotropical Entomology, Londrina, v.34, n.6, p.889-894, 2005.
ARAUJO, E. L.; ZUCCHI, R. A. Parasitóides (Hymenoptera: Braconidae) de moscas-das-frutas (Diptera: Tephritidae) na região de Mossoró/Assú, Estado do Rio Grande do Norte. Arquivos do Instituto Biológico, São Paulo, v.69, n.2, p.65-68, 2002.

AYRES, M.; AYRES, J. R. M.; AYRES, D. L.; SANTOS A. S. BioEstat 5.0: aplicações estatísticas nas áreas das ciências biológicas e médicas. 5.ed. Belém: Sociedade Civil Mamirauá/ Conselho Nacional de Desenvolvimento Científico e Tecnológico, 2007.

AZEVEDO, F.R.; GUIMARÃES, J.A.; SIMPLÍCIO, A.A.F.; SANTOS, H.R. Análise faunística e flutuação populacional de moscas-das-frutas (Diptera: Tephritidae) em pomares comerciais de goiaba na região do Cariri cearense. Arquivos do Instituto Biológico, São Paulo, v.77, n.1, p.33-41, 2010.

BITTENCOURT, M.A.L.; SANTOS, O.O.; BRITO, E.A.; ARAUJO, E.L.; MARINHO, C.F. Parasitóides (Braconidae) associados à Anastrepha (Tephritidae) em frutos hospedeiros do Litoral Sul da Bahia. Revista Ciência Agronômica, Fortaleza, v.43, n.4, p.811-815, 2012.

CANAL, N.A.; ZUCCHI, R.A. Parasitóides - Braconidae. In: MALAVASI, A.; ZUCCHI, R.A. (Ed.). Moscas-das-frutas de importância econômica no Brasil: conhecimento básico e aplicado. São Paulo: Holos, 2000. p.119-126.

CARVALHO, R.S. Metodologia para monitoramento populacional de moscas-dasfrutas em pomares comerciais. Cruz das Almas: Embrapa Mandioca e Fruticultura, 2005. 17 p. (Circular Técnica, 75).

GARCIA, F.R.M.; NORRBOM, A.L. Tephritoid flies (Diptera, Tephritoidea) and their plant hosts from the state of Santa Catarina in Southern Brazil. Florida Entomologist, Gainesville, v.94, n.2, p.151-157, 2011.

DE DEUS, E.G.; ADAIME, R. Dez anos de pesquisas sobre moscas-das-frutas (Diptera: Tephritidae) no estado do Amapá: avanços obtidos e desafios futuros. Biota Amazônia, Macapá, v.3, n.3, p.157168, 2013. 
GODOY, M.J.S.; PACHECO, W.S.P.; MALAVASI, A. Moscas-das-frutas quarentenárias para o Brasil. In: SILVA, R.A.; LEMOS, W.P.; ZUCCHI, R.A. (Ed.). Moscas-das-frutas na Amazônia brasileira: diversidade, hospedeiros e inimigos naturais. Macapá: Embrapa Amapá, 2007. p.111-131.

INMET. Instituto Nacional de Meteorologia. Dados climáticos históricos. 2013. Disponível em: $<\underline{\text { http: } / /}$ www.inmet.gov.br/portal/index.php? $\mathrm{r}=\mathrm{bdmep} /$ bdmep >. Acesso em: 22 jan. 2013.

KOVALESKI, A.; SUGAYAMA, R.L.; URAMOTO, K.; MALAVASI, A. Rio Grande do Sul In: MALAVASI, A.; ZUCCHI, R. A. (Ed.). Moscasdas-frutas de importância econômica no Brasil: conhecimento básico e aplicado. Ribeirão Preto: Holos, 2000. p.285-290.

LEAL, M.R.; SOUZA, S.A.S.; AGUIARMENEZES, E.L.; LIMA FILHO, M.; MENEZES, E.B. Diversidade de moscas-das-frutas, suas plantas hospedeiras e seus parasitóides nas regiões Norte e Noroeste do Estado do Rio de Janeiro, Brasil. Ciência Rural, Santa Maria, v.39, n.3, p.627-634, 2009.

MARGALEF, R. Homage to Evelyn Hutchinson, or why is there an upper limit to diversity. Transactions of the Connecticut Academy of Arts and Sciences, Connecticut, v.14, p.211-235, 1972.

MALAVASI, A.; MORGANTE, J.S. Biologia de moscas-das-frutas (Diptera: Tephritidae). II. Índices de infestação em diferentes hospedeiros e localidades. Revista Brasileira de Biologia, Rio de Janeiro, v.40, n.1, p.17-24, 1980.

MALAVASI, A.; ZUCCHI, R.A.; SUGAYAMA, R.L. Biogeografia. In: MALAVASI, A; ZUCCHI, R.A. (Ed.). Moscas-das-frutas de importância econômica no Brasil: conhecimento básico e aplicado. Ribeirão Preto: Holos, 2000. p.93-98.

MARINHO, C.F; SILVA, R.A.; ZUCCHI, R.A. Chave de identificação de Braconidae (Alysiinae e Opiinae) parasitóides de larvas frugívoras na região Amazônica. In: SILVA, R.A.; LEMOS, W.P.; ZUCCHI, R.A. (Ed.). Moscas-das-frutas na Amazônia brasileira: diversidade, hospedeiros e inimigos naturais. Macapá: Embrapa Amapá, 2011. p.91-101.
MEDEIROS, R.M. Climatologia do município de

Teresina. Teresina: Secretaria do Meio Ambiente e Recursos naturais do Espado do Piauí, 2006. 28p.

MONTES, S.M.N.M.; RAGA, A.; BOLIANI, A.C.; SANTOS, P.C. Dinâmica populacional e incidência de moscas-das-frutas e parasitóides em cultivares de pessegueiros (Prunus persica L. Batsch) no município de Presidente Prudente, SP. Revista Brasileira de Fruticultura, Jaboticabal, v.33, n.2, p.402-411, 2011.

MONTES, S. M. N.M.; RAGA, A.; SOUZA-FILHO, M. F. Moscas-das-frutas na região de Presidente Prudente, SP. São Paulo: Instituto Biológico-APTA, 2013. p.1-17. (Documento técnico 16).

MONTES, S.M.N.M.; RAGA, A.; BOLIANI, A.C.; SANTOS, P.C. Dinâmica populacional e incidência de moscas-das-frutas e parasitoides em cultivares de pessegueiros (Prunus persica 1. Batsch) no município de Presidente Prudente-SP. Revista Brasileira de Fruticultura, Jaboticabal, v.33, n.2, p.402-411, 2011.

MORAES, R.C.B.; HADDAD, M.L.; SILVEIRA NETO, S.; REYES, A.E.L. Software para análise faunística. In: SIMPÓSIO DE CONTROLE BIOLÓGICO, 8., 2003, São Pedro. Anais... São Pedro: Sincobiol, 2003. v.1, p.195.

PARANHOS, B.A.J.; WALDER, J.M.M.; ALVARENGA, C.D. Parasitismo de Larvas de Mosca-do-Mediterrâneo por Diachasmimorpha longicaudata (Ashmead) (Hymenoptera: Braconidae) em Diferentes Cultivares de Goiaba. Neotropical Entomology, Londrina, v.36, n.2, p.243-246, 2007.

PIROVANI, V.D.; MARTINS, D.S.; SOUZA, S.A.S.; K.URAMOTO, K.; FERREIRA, P.S.F. Moscas-das-frutas (Diptera: Tephritidae), seus parasitóides e hospedeiros em Viçosa, zona-da-mata mineira. Arquivos do Instituto Biológico, São Paulo, v.77, n.4, p.727-733, 2010.

SACRAMENTO, C.K.; SOUZA, F.X.Cajá.In: SANTOS-SEREJO, J.A.; DANTAS, J.L.L.; SAMPAIO, C.V.; COELHO, Y. da. S. (Ed.). Fruticultura tropical: espécies regionais e exóticas. Brasília: Embrapa Informação Tecnológica, 2009. p. 85 . 
SANTANA, F.F. Caracterização de genótipo de cajazeiras. 2010. $97 \mathrm{f}$. Tese (Doutorado em Agronomia) - Faculdade de Ciências Agrárias e Veterinárias,Universidade Estadual Paulista, Jaboticabal, 2010.

SANTOS, O.O.; MELO, E.A.S.F.; ROCHA, R.B.; OLIVEIRA, R.A.; BITTENCOURT, M.A.L. Atividade inseticida de produtos de origem vegetal sobre moscas-das-frutas (Diptera: Tephritidae) e broca-rajada (Coleoptera: Curculionidae). Magistra, Cruz das Almas, v.24, p.26-31, 2012. Número especial.

SELIVON, D. Relações com as plantas hospedeiras. In: MALAVASI, A.; ZUCCHI, R. A. (Ed.). Moscasdas-frutas de importância econômica no Brasil: conhecimento básico e aplicado. Ribeirão Preto: Holos Editora, 2000. p.87-91.

SIEGEL, S.; CASTELLAN JÚNIOR, N.J. Estatística não paramétrica para ciências do comportamento. 2. ed. Porto Alegre: Artmed. 2006. 448 p.

SILVA JUNIOR, J.F.; BEZERRA, J.E.F.; LEDERMAN, I.E.; ALVES, M.A.; MELO NETO, M.L. de. Collecting, ex situ conservation and characterization of "cajá-umbu" (Spondias mombin $x$ Spondias tuberosa) germoplasmin Pernambuco State, Brasil. Genetic Resources and Crop Evolution, Dordrecht, v.51, p.343-349, 2004.

SILVEIRA NETO, S.; MONTEIRO, R.C.; ZUCCHI, R.A; MORAES, R.C.B. Uso da análise faunística de insetos na avaliação do impacto ambiental. Scientia Agrícola, Piracicaba, v.52, n.1, p.9-15, 1995.

SILVEIRA NETO, S.; NAKANO, O.; BARBIN, D.; VILLA NOVA, N.A. Manual de ecologia dos insetos. São Paulo: Editora Ceres, 1976. 419 p.

SOUZA-FILHO, M. F. Infestação de moscasdas-frutas (Diptera: Tephritidae e Lonchaeidae) relacionada à fenologia da goiabeira (Psidium guajava L.), nespereira (Eriobotrya japônica Lindl.) e do pessegueiro (Prunus persica Batsch). 2006. 125 f. Tese (Doutorado em Ciências) Escola Superior de Agricultura Luiz de Queiroz, Universidade de São Paulo, Piracicaba, 2006.

SOUZA-FILHO, M.F.; RAGA, A.; AZEVEDOFILHO, J.A.; STRIKIS, PC.; GUIMARÃES, J.A.; ZUCCHI, .RA. Diversity and seasonality of fruit flies (Diptera: Tephritidae and Lonchaeidae) and their parasitoids (Hymenoptera: Braconidae and Figitidae) in orchards of guava, loquat and peach. Brazilian Journal of Biology, São Carlos, v.69, n.1, p.31-40, 2009.

SOUZA-FILHO, M.F.; RAGA, A.; ZUCCHI, R.A. Incidência de Anastrepha obliqua (Macquart) y Ceratitiscapitata (Wiedemann) (Diptera: Tephritidae) en carambola (Averrhoa carambola L.) enocho localidades del estado de São Paulo, Brasil. Anais da Sociedade Entomológica do Brasil, Jaboticabal, v.29, n.2, p.367-371, 2000.

SUPLICY FILHO, N.; SAMPAIO, A.S.; MYAZAKI, I.; BITRAN, E.A.; OLIVEIRA, D.A.; VEIGA, A.A. Estudo de fatores determinantes do grau de suscetibilidade ao parasitismo por "moscas das frutas" Anastrepha spp., em cinco variedades de goiaba. Biológico, São Paulo, v.50, n.8, p.169-176, 1984.

URAMOTO, K.; WALDER, J.M.M.; ZUCCHI, R.A. Biodiversidade de moscas-das-frutas do gênero Anastrepha (Diptera, Tephritidae) no campus da ESALQ-USP, Piracicaba, São Paulo. Revista Brasileira de Entomologia, São Paulo, v.48, n.3, p.409-414, 2004.

URAMOTO, K.; WALDER, J.M.M.; ZUCCHI, R.A. Análise quantitativa e distribuição de populações de espécies de Anastrepha (Diptera: Tephritidae) no campus Luiz de Queiroz, Piracicaba, São Paulo. Neotropical Entomology, Londrina, v.34, n.1, p.3339, 2005.

ZUCCHI, R. A. Fruit flies in Brazil: Anastrepha species their host plants and parasitoids. 2008. Disponível em: <http://www.lea.esalq.usp.br/ anastrepha/ $>$. Acesso em: 7 out. 2012

ZUCCHI, R.A.Taxonomia.In: MALAVASI, A.; ZUCCHI, R.A. (Ed.). Moscas-das-frutas de importância econômica no Brasil: conhecimento básico e aplicado. Ribeirão Preto: Holos, 2000a. p.13-24.

ZUCCHI, R.A. Espécies de Anastrepha, sinonímias, plantas hospedeiras e parasitóides. In: MALAVASI, A.; ZUCCHI, R.A. (Ed.). Moscas-das-frutas de importância econômica no Brasil: conhecimento básico e aplicado. Ribeirão Preto: Holos, 2000b. p.41-48. 